\title{
Soil Processes Affected by Sixteen Grassland Species Grown under Different Environmental Conditions
}

\author{
Feike A. Dijkstra,* Sarah E. Hobbie, and Peter B. Reich
}

\begin{abstract}
Plant species, and their interactions with the environment, determine both the quantity and chemistry of organic matter inputs to soils. Indeed, countless studies have linked the quality of organic matter inputs to litter decomposition rates. However, few studies have examined how variation in the quantity and chemistry of plant inputs, caused by either interspecific differences or changing environmental conditions, influences the dynamics of soil organic matter. We studied the effects of 16 grassland species from 4 functional groups $(\mathrm{C} 3$ and $\mathrm{C} 4$ grasses, forbs, and legumes) growing under ambient and elevated $\mathrm{CO}_{2}$ $(560 \mathrm{ppm})$ and $\mathrm{N}$ inputs $\left(4 \mathrm{~g} \mathrm{~m}^{-2} \mathrm{yr}^{-1}\right)$ on soil carbon $(C)$ and nitrogen (N) dynamics after $4 \mathrm{yr}$ in a grassland monoculture experiment in Minnesota, USA. Specifically, we related soil $\mathbf{C}$ and $\mathbf{N}$ dynamics to variation among species and their responses to the $\mathrm{CO}_{2}$ and $\mathrm{N}$ treatments in plant biomass and chemistry of roots, the dominant detrital input in the system. The 16 species caused much larger variation in plant litter inputs and chemistry, as well as soil $\mathrm{C}$ and $\mathrm{N}$ dynamics, than the $\mathrm{CO}_{2}$ and $\mathrm{N}$ treatment. Not surprising, variation in the quantity of plant inputs to soils contributed to up to a two-fold variation in microbial biomass and amount of respired nonlabile soil $\mathrm{C}$. Root $\mathrm{N}$ concentration (across species and $\mathrm{CO}_{2}$ and $\mathrm{N}$ treatments) was significantly negatively related to decomposition of nonlabile soil $\mathrm{C}$ and positively related to net $\mathbf{N}$ mineralization. Greater labile $\mathrm{C}$ inputs decreased rates of net $\mathbf{N}$ mineralization, likely because of greater $\mathbf{N}$ immobilization. Thus, of the traits examined, plant productivity, tissue $N$ concentration, and labile $\mathrm{C}$ production such as from rhizodeposition were most important in causing variation in soil $\mathrm{C}$ and $\mathrm{N}$ dynamics among species and in response to altered atmospheric $\mathrm{CO}_{2}$ and $\mathrm{N}$ supply.
\end{abstract}

TCREASED ATMOSPHERIC $\mathrm{CO}_{2}$ concentration and $\mathrm{N}$ deposition are potentially altering the structure and functioning of many terrestrial ecosystems (Vitousek, 1994). These global change factors influence the amount and chemistry of primary productivity as well as cause shifts in the relative abundances of species and functional groups that themselves differ from one another in their productivity and chemical composition (Reich et al., 2001a).

The amount (i.e., dry mass) and chemistry of plant litter inputs have long been known to affect fresh litter decomposition and nutrient release (e.g., Hobbie, 1992; Mack and D'Antonio, 2003; Melillo et al., 1982). Differences among and changes in plant communities have been shown to affect soil organic matter pools and dynamics through interspecific differences in litter quantity

F.A. Dijkstra and S.E. Hobbie, Dep. of Ecology, Evolution, and Behavior, Univ. of Minnesota, St. Paul, MN 55108, USA; P.B. Reich, Dep. of Forest Resources, Univ. of Minnesota, St. Paul, MN 55108, USA; F.A. Dijkstra, current address: Dep. of Environmental Studies, Univ. of California, 1156 High St., Santa Cruz, CA 95064, USA. Received 24 Mar. 2005. *Corresponding author (dijkstra@ucsc.edu).

Published in Soil Sci. Soc. Am. J. 70:770-777 (2006).

Soil Biology \& Biochemistry, Forest, Range \& Wildland Soils, Soil Fertility \& Plant Nutrition

doi:10.2136/sssaj2005.0088

(C) Soil Science Society of America

677 S. Segoe Rd., Madison, WI 53711 USA and chemistry (Eviner and Chapin, 2004; Finzi et al., 1998; Knicker et al., 2000), but also through interspecific differences in rhizodeposition of labile $\mathrm{C}$ compounds (Cheng et al., 2003; Fu and Cheng, 2002; Reid and Goss, 1982). Similarly, interspecific differences in litter quantity and chemistry and labile $\mathrm{C}$ production through rhizodeposition play an important role in soil $\mathrm{N}$ dynamics (Eviner and Chapin, 2004; Wedin and Tilman, 1990), but their relative importance remains unclear.

It is also unclear how important species-specific changes in litter quantity, chemistry and labile $\mathrm{C}$ production caused by elevated atmospheric $\mathrm{CO}_{2}$ and $\mathrm{N}$ supply are on soil organic matter and $\mathrm{N}$ dynamics, compared with plant species or community effects. Although elevated atmospheric $\mathrm{CO}_{2}$ and $\mathrm{N}$ supply can alter litter quantity, chemistry, and labile $\mathrm{C}$ production (e.g., Cheng and Johnson, 1998; Hobbie and Vitousek, 2000), their effect on soil organic matter and $\mathrm{N}$ dynamics may be limited compared with plant community effects (Aerts et al., 2003; Finzi and Schlesinger, 2002). Nonetheless, litter quantity and chemistry (including both nutrient and $\mathrm{C}$ chemistry) and labile $\mathrm{C}$ production may serve to integrate influences of species trait differences (both within and among functional groups) as well as trait responses to atmospheric $\mathrm{CO}_{2}$ and $\mathrm{N}$ supply on soil organic matter dynamics.

The aim of this study was to assess how soil microbial biomass, soil organic matter, and $\mathrm{N}$ dynamics are affected by 16 grassland species grown under ambient and elevated atmospheric $\mathrm{CO}_{2}(560 \mathrm{ppm})$ with 0 or $4 \mathrm{~g}$ $\mathrm{m}^{-2} \mathrm{yr}^{-1}$ of $\mathrm{N}$ fertilizer. We also examined the degree to which the quantity and chemistry of litter inputs and labile $\mathrm{C}$ production influence soil $\mathrm{C}$ and $\mathrm{N}$ dynamics under the different treatments. In a companion paper, we have reported the main effects of $\mathrm{CO}_{2}, \mathrm{~N}$, plant species richness, and their interactions on microbial biomass and activity (Dijkstra et al., 2005). Whereas the previous paper compared the monoculture plots to more speciesrich plots to determine how increasing species richness (along with elevated $\mathrm{CO}_{2}$ and $\mathrm{N}$ ) affects soil processes, here we focus on comparisons among the different monocultures themselves (i.e., among different species) to determine the relationship between plant traits and aspects of soil $\mathrm{C}$ and $\mathrm{N}$ dynamics such as $\mathrm{C}$ and $\mathrm{N}$ mineralization and microbial $\mathrm{C}$ and $\mathrm{N}$, under ambient and elevated $\mathrm{CO}_{2}$, with and without $\mathrm{N}$ fertilization.

\section{MATERIALS AND METHODS}

\section{Study Site}

This research is part of the BioCON (Biodiversity, $\mathrm{CO}_{2}$, and N) experiment (Reich et al., 2001a; Reich et al., 2001b)

Abbreviations: ANOVA, analysis of variance; BioCON, Biodiversity, $\mathrm{CO}_{2}$, and $\mathrm{N}$; FACE, free-air $\mathrm{CO}_{2}$ enrichment. 
established in an old field in the Cedar Creek Natural History Area (CCNHA), Minnesota, USA ( $\left.45^{\circ} 24^{\prime} \mathrm{N}, 93^{\circ} 12^{\prime} \mathrm{W}\right)$. Soils (Argic Udipsamments) in this nearly level area are very homogenous, sandy (93\% sand, $3 \%$ silt, and $4 \%$ clay) and poor in soil organic matter and $\mathrm{N}$ content (on average $0.6 \%$ total $\mathrm{C}$ and $0.06 \%$ total $\mathrm{N}$ ). Mean annual precipitation is $660 \mathrm{~mm}$ with mean monthly temperatures of $-11^{\circ} \mathrm{C}$ in January and $22^{\circ} \mathrm{C}$ in July. Vegetation (secondary successional grassland) was removed from six circular rings (diam. $20 \mathrm{~m}$ ) in 1997 and planted with perennial grassland species in 2 by $2 \mathrm{~m}$ plots. For our study, we used 128 monoculture plots of 16 different species, distributed nearly equally among the 6 rings. The 16 species that were used (all native or naturalized to the CCNHA) are the $\mathrm{C}_{4}$ grasses Andropogon gerardii Vitman, Bouteloua gracilis, Schizachyrium scoparium (Michaux) Nash, and Sorghastrum nutans (L.) Nash; the $\mathrm{C}_{3}$ grasses Agropyron repens (L.) Beauv., Bromus inermis Leysser, Koeleria cristata Pers, and Poa pratensis L.; the forbs Achillea millefolium L., Anemone cylindrica A. Gray, Asclepias tuberosa L., and Solidago rigida L.; and the legumes Amorpha canescens Pursh, Lespedeza capitata Michaux, Lupinus perennis L., and Petalostemum villosum Nutt. Three rings received elevated atmospheric $\mathrm{CO}_{2}$ concentrations $(560 \mathrm{ppm}$, a concentration expected to occur globally by 2050) during four growing seasons (1998-2001), using the free-air $\mathrm{CO}_{2}$ enrichment (FACE) system. Half of the plots in each treatment were fertilized with $4 \mathrm{~g} \mathrm{~N} \mathrm{~m}^{-2} \mathrm{yr}^{-1}$ (comparable with $\mathrm{N}$ deposition rates in industrialized areas) as $\mathrm{NH}_{4} \mathrm{NO}_{3}$, applied in three equal doses during the growing season. The experimental treatments of species (16 species), $\mathrm{CO}_{2}$ (two levels), and $\mathrm{N}$ (two levels) were arranged in a complete factorial design with two replicates $(16 \times 2 \times 2 \times 2)$. Plots were regularly weeded to remove all species other than assigned, watered only in the first year. Plots were also burned two out of every $3 \mathrm{yr}$, which is a common management practice at CCNHA. For a detailed description of the experimental design see Reich et al. (2001b).

\section{Sampling and Analyses}

We used total plant biomass (above- and belowground) sampled in June and August of 1998, 1999, and 2000 (see Reich et al., 2001b) to test for plant biomass effects on soil $\mathrm{C}$ and $\mathrm{N}$ dynamics (see below). Aboveground biomass was clipped in 10 by $100 \mathrm{~cm}$ strips just above the soil surface, all matter was collected, dried and weighed. Roots were sampled at 0 - to 20 -cm depth using three cores (diam. $5 \mathrm{~cm}$ ) in the area used for the aboveground biomass clipping. Roots were washed, dried, and weighed. In this herbaceous system aboveground biomass is a good estimate of aboveground productivity (and litter inputs); because we do not have good estimates of root productivity, we used root standing stocks of root biomass along with aboveground biomass as an estimate of total plant inputs (Zak et al., 2003).

We analyzed roots sampled in August 1999 for chemical characteristics that we related to soil $\mathrm{C}$ and $\mathrm{N}$ dynamics. We focused on roots because they represent roughly three-fourths of plant biomass in these grassland ecosystems (Reich et al., 2001a) and are a critical source of litter inputs (especially given that residual aboveground litter is burned two out of every $3 \mathrm{yr}$ ). We analyzed roots for $\mathrm{N}$ on an Element Analyzer (ECS 4010, Costech Analytical Technologies, Valencia, CA) and cell soluble compounds, hemicellulose, cellulose, and lignin and related recalcitrant materials on an Ankom Fiber Analyzer (Ankom Tech., Fairport, NY) according to Van Soest (1994).

In June 2001, we sampled three soil cores (diam. $2.5 \mathrm{~cm}$ ) at 0 - to $20-\mathrm{cm}$ depth from each of the 128 plots. We sieved soils $(2 \mathrm{~mm})$ and removed most of the roots. Subsamples were taken for measurements of gravimetric water content $\left(105^{\circ} \mathrm{C}, 48 \mathrm{~h}\right)$, soil C respiration, microbial biomass, and net $\mathrm{N}$ mineralization.

We incubated soils for $74 \mathrm{~d}$ under optimum moisture conditions $\left(70 \%\right.$ of field capacity) at room temperature $\left(22^{\circ} \mathrm{C}\right)$ to measure soil $\mathrm{C}$ respiration. By keeping temperature and moisture constant, we were able to separate the influence of plants on soil $\mathrm{C}$ respiration (and on net $\mathrm{N}$ mineralization, below) via litter quantity and chemistry from their effects on microclimate. Although plants can have large effects on microclimate in the field, potentially altering microbial processes, our objective in this study was to isolate litter quantity and chemistry effects. We measured soil $\mathrm{C}$ respiration from the incubated soils on Day 2, 6, 11, 20, 41, and 74 after field sampling by taking headspace samples from soil samples incubated in mason jars, and analyzing the $\mathrm{CO}_{2}$ on a gas chromatograph (Shimadzu GC14A, see Dijkstra et al., 2005). Daily soil C respiration rates dropped rapidly and became almost stable after $74 \mathrm{~d}$ of incubation. We assumed that this pattern reflected a depletion of labile $\mathrm{C}$ early during the incubation and a constant soil $\mathrm{C}$ respiration rate of more recalcitrant or nonlabile $\mathrm{C}$ throughout the incubation (Townsend et al., 1997).

We separated soil C respiration of fast versus slow cycling C by fitting a two-order model through the cumulative soil $\mathrm{C}$ respiration over time (Bonde and Rosswall, 1987; Wedin and Pastor, 1993) for each sample:

$$
C_{t}=C_{l}\left(1-e^{-k t}\right)+c t
$$

where $C_{t}$ is the cumulative amount of $\mathrm{C}$ respired at time $t, C_{l}$ and $k$ are the fast or labile $\mathrm{C}$ pool size and its respiration rate constant respectively, and $c$ is the constant nonlabile soil $\mathrm{C}$ respiration rate. Because of its short-lived nature, we assumed the labile $\mathrm{C}$ pool to be directly coming from recent plant inputs (e.g., labile C compounds in litter and root exudates). Because the curve fitting did not always converge, we improved the curve fitting by estimating $c$ separately by fitting the daily soil $\mathrm{C}$ respiration rate measurements with the derivative of Eq. [1]

$$
R_{t}=a e^{-k t}+c
$$

where $R_{t}$ is the daily soil $\mathrm{C}$ respiration rate at time $t$, and $a$ the daily soil $\mathrm{C}$ respiration rate at time 0 (equal to $C_{1} \times k$ ). All curve-fitting was performed with Sigmaplot (version 5.0; Systat Software Inc., Richmond, CA). The random pattern of residual plots indicated that the models used were adequately describing the data.

We measured microbial biomass $\mathrm{C}$ and $\mathrm{N}$ using the fumigation-extraction method (Brookes et al., 1985). Extracts $\left(0.5 \mathrm{M} \mathrm{K}_{2} \mathrm{SO}_{4}\right)$ from nonfumigated and fumigated soil samples were analyzed for total dissolved $\mathrm{C}$ and $\mathrm{N}$ on a total organic $\mathrm{C}$ analyzer with a N-measuring unit attached (Shimadzu TOC$\mathrm{V}_{\mathrm{CPN}}$, Shimadzu Scientific Instruments, Columbia, MD). Microbial $\mathrm{C}$ and $\mathrm{N}$ were calculated as the difference in $\mathrm{C}$ and $\mathrm{N}$ between the extracts from the nonfumigated and fumigated soil samples, divided by 0.45 for C (Beck et al., 1997) and by 0.54 for N (Brookes et al., 1985).

Net $\mathrm{N}$ mineralization was measured during a 10 -d period in soil laboratory incubations by extracting soil subsamples (moistened to $70 \%$ field capacity) at the beginning and end of incubation with $1 \mathrm{M} \mathrm{KCl}$ and analyzing extracts for $\mathrm{NO}_{3}$ and $\mathrm{NH}_{4}{ }^{+}$on an Alpkem auto-analyzer (see Dijkstra et al., 2005). Net $\mathrm{N}$ mineralization during a short-term incubation period such as ours has shown to be a good indicator for how plant litter inputs affect net $\mathrm{N}$ mineralization rates in the field at Cedar Creek (Wedin and Pastor, 1993).

We used ANOVA to test for main effects of $\mathrm{CO}_{2}$ (ambient or elevated), $\mathrm{N}$ ( 0 or $\left.4 \mathrm{~g} \mathrm{~m}^{-2} \mathrm{yr}^{-1}\right)$, and either species identity (among 16 species) or functional group identity $\left(C_{3}\right.$ grasses, $C_{4}$ 
Table 1. Mean values \pm standard error for total plant biomass, root chemistry, labile $\mathrm{C}$, its respiration rate constant $(k)$, nonlabile soil $\mathrm{C}$ respiration rate (c), net $\mathrm{N}$ mineralization and microbial biomass averaged by $\mathrm{CO}_{2}$ (pooled across $\left.\mathrm{N}, n=96\right)$ and $\mathrm{N}$ treatment (pooled across $\left.\mathrm{CO}_{2}, n=96\right)$ both averaged across species with statistical probabilities $\left(P\right.$-values) for $\mathrm{CO}_{2}$ and $\mathrm{N}$ treatment effects from analysis of variance (ANOVA, $\mathrm{CO}_{2} \times \mathbf{N} \times$ Species identity model). Species identity treatment effects are shown in Tables 2 and 3 . There were no significant $(P<0.05)$ interactions between the $\mathrm{CO}_{2}, \mathrm{~N}$, and species identity treatments, except for total plant biomass $\left(\mathrm{CO}_{2} \times\right.$ species: $P=0.05, N \times$ species: $P=0.05)$ and root $N$ concentration $(N \times$ species: $P=0.003)$.

\begin{tabular}{|c|c|c|c|c|c|c|}
\hline Parameter & Ambient $\mathrm{CO}_{2}$ & Elevated $\mathrm{CO}_{2}$ & $P$-value & Unfertilized & Fertilized & $P$-value \\
\hline Tot. plant biomass, $\mathrm{g} \mathrm{m}^{-2}$ & $664 \pm 37$ & $751 \pm 39$ & 0.02 & $673 \pm 35$ & $742 \pm 41$ & 0.005 \\
\hline $\operatorname{Root} \mathbf{N}, \%$ & $1.19 \pm 0.07$ & $1.15 \pm 0.07$ & 0.59 & $1.15 \pm 0.08$ & $1.19 \pm 0.06$ & 0.36 \\
\hline Root cell soluble, \% & $34.4 \pm 1.6$ & $33.9 \pm 1.5$ & 0.74 & $34.7 \pm 1.6$ & $33.6 \pm 1.5$ & 0.33 \\
\hline Root hemicellulose, \% & $24.7 \pm 0.9$ & $25.3 \pm 0.9$ & 0.44 & $25.0 \pm 1.0$ & $25.1 \pm 0.9$ & 0.87 \\
\hline Root cellulose, \% & $25.3 \pm 0.6$ & $25.8 \pm 0.6$ & 0.54 & $24.8 \pm 0.5$ & $26.2 \pm 0.6$ & 0.004 \\
\hline Root lignin, \% & $15.2 \pm 0.5$ & $14.6 \pm 0.4$ & 0.68 & $15.0 \pm 0.5$ & $14.7 \pm 0.5$ & 0.52 \\
\hline Root lignin/N & $14.8 \pm 0.9$ & $14.7 \pm 0.7$ & 0.94 & $15.6 \pm 0.8$ & $13.8 \pm \mathbf{0 . 8}$ & 0.02 \\
\hline Labile C, mg kg ${ }^{-1}$ & $90 \pm 5$ & $105 \pm 6$ & 0.08 & $111 \pm 9$ & $85 \pm 8$ & $\mathbf{0 . 0 1}$ \\
\hline$K, d^{-1}$ & $0.047 \pm 0.002$ & $0.048 \pm 0.002$ & 0.50 & $0.043 \pm 0.002$ & $0.052 \pm 0.003$ & 0.001 \\
\hline$c, \mathrm{mg} \mathrm{kg}^{-1} \mathbf{d}^{-1}$ & $4.67 \pm 0.16$ & $5.03 \pm 0.19$ & 0.34 & $4.63 \pm 0.15$ & $5.08 \pm 0.20$ & 0.02 \\
\hline Net $\mathrm{N}$ min., $\mathrm{mg} \mathrm{kg}^{-1} \mathrm{~d}^{-1}$ & $\mathbf{0 . 1 7} \pm \mathbf{0 . 0 2}$ & $\mathbf{0 . 1 5} \pm \mathbf{0 . 0 2}$ & 0.34 & $\mathbf{0 . 1 3} \pm \mathbf{0 . 0 2}$ & $\mathbf{0 . 1 9} \pm \mathbf{0 . 0 2}$ & 0.02 \\
\hline Microbial C, mg kg & $116 \pm 4$ & $135 \pm 4$ & 0.15 & $130 \pm 4$ & $120 \pm 5$ & 0.07 \\
\hline Microbial N, mg kg ${ }^{-1}$ & $14.1 \pm 0.6$ & $16.9 \pm 0.7$ & 0.16 & $16.9 \pm 0.6$ & $14.1 \pm 0.7$ & 0.0002 \\
\hline
\end{tabular}

grasses, forbs, and legumes), and their interactions. Here we focus on species identity, functional group identity, and their interactions with the $\mathrm{CO}_{2}$ and $\mathrm{N}$ treatment, while main effects of $\mathrm{CO}_{2}, \mathrm{~N}$, and plant diversity and all interactions among these are reported elsewhere (Dijkstra et al., 2005). The effect of the $\mathrm{CO}_{2}$ treatment was tested against the random effect of ring nested within the $\mathrm{CO}_{2}$ treatment. All treatment effects were considered as fixed factors. We used simple and multiple regressions to relate total plant biomass, root tissue chemistry, and labile $\mathrm{C}$ (determined from incubations) to microbial biomass and net $\mathrm{N}$ mineralization, and to relate total plant biomass and root tissue chemistry to $c$. We could not test for the effect of labile $\mathrm{C}$ on $c$ because they were not estimated independently. For multiple regressions all independent variables were standardized to unit-free variables with a mean equal to zero and a variance equal to one. All statistical analyses were done with JMP (version 4.0.4, SAS Institute, Cary, NC).

\section{RESULTS}

Elevated $\mathrm{CO}_{2}$ and $\mathrm{N}$ fertilization effects on total plant biomass, root chemistry, labile $\mathrm{C}, k, c$, microbial $\mathrm{C}$ and $\mathrm{N}$, and net $\mathrm{N}$ mineralization averaged across all 16 species grown as monocultures are summarized in Table 1. Briefly, elevated $\mathrm{CO}_{2}$ significantly increased total plant biomass (13\%), and $\mathrm{N}$ fertilization significantly increased total plant biomass $(10 \%)$, root cellulose concentration $(6 \%), k(21 \%), c(10 \%)$, and net $\mathrm{N}$ mineralization (46\%), and significantly decreased root lignin/ $\mathrm{N}$ ratio $(13 \%)$, labile $\mathrm{C}(31 \%)$, and microbial $\mathrm{N}(20 \%)$.

Total plant biomass and root chemistry showed large and significant differences among species (Table 2) giving rise to a large potential to alter soil $\mathrm{C}$ and $\mathrm{N}$ dynamics (see below). Differences in total plant biomass among species after $4 \mathrm{yr}$ of treatment were similar to those reported for the first $2 \mathrm{yr}$ of the experiment (Reich et al., 2001a). The $\mathrm{C} 3$ and $\mathrm{C} 4$ grasses were the functional groups with the greatest average biomass, with two $\mathrm{C} 3$ grasses, $A$. repens and $P$. pratensis, having the greatest and A. tuberosa (a forb) and A. canescens (a legume) having the smallest biomass of all the species. However, we found only weak evidence for significant differences

Table 2. Mean values \pm standard error for total plant biomass and root chemistry of the 16 different species averaged over the $\mathrm{CO}_{2}$ and $\mathrm{N}$ treatment $(n=8)$ with statistical probabilities $(P$-values) for species and functional group identity effects from analysis of variance $\left(\right.$ ANOVA, $\mathrm{CO}_{2} \times \mathrm{N} \times$ Species identity and $\mathrm{CO}_{2} \times \mathrm{N} \times$ Functional group identity models respectively). $\mathrm{CO}_{2}$ and $\mathrm{N}$ treatment effects are shown in Table 1.

\begin{tabular}{|c|c|c|c|c|c|c|c|c|}
\hline Functional group & Plant species & Tot. plant biomass & $\mathbf{N}$ & Cell soluble & Hemicellulose & Cellulose & Lignin & Lignin/N \\
\hline & & $\mathbf{g ~ m}^{-2}$ & & & $-\%$ & & & \\
\hline \multirow[t]{5}{*}{ C4 grasses } & A. gerardii & $857 \pm 37$ & $0.81 \pm 0.09$ & $26.4 \pm 1.6$ & $30.7 \pm 0.8$ & $27.0 \pm 0.9$ & $15.7 \pm 0.5$ & $20.8 \pm 2.1$ \\
\hline & B. gracilis & $672 \pm 37$ & $1.06 \pm 0.08$ & $20.8 \pm 0.9$ & $34.5 \pm 0.9$ & $26.9 \pm 0.7$ & $17.5 \pm 0.9$ & $16.8 \pm 0.7$ \\
\hline & S. scoparium & $632 \pm 35$ & $0.99 \pm 0.09$ & $24.5 \pm 1.4$ & $32.1 \pm 1.0$ & $29.1 \pm 0.4$ & $14.0 \pm 0.5$ & $21.0 \pm 1.6$ \\
\hline & S. nutans & $734 \pm 43$ & $0.78 \pm 0.03$ & $22.9 \pm 0.6$ & $32.4 \pm 0.4$ & $29.1 \pm 1.0$ & $15.5 \pm 0.8$ & $19.8 \pm 0.9$ \\
\hline & Mean & $724 \pm 24$ & $0.83 \pm 0.04$ & $23.6 \pm 0.7$ & $32.4 \pm 0.5$ & $28.0 \pm 0.4$ & $15.7 \pm 0.4$ & $19.6 \pm 0.8$ \\
\hline \multirow[t]{5}{*}{ C3 grasses } & A. repens & $1147 \pm 72$ & $0.76 \pm 0.05$ & $45.3 \pm 0.7$ & $23.9 \pm 0.4$ & $21.7 \pm 0.5$ & $8.9 \pm 0.4$ & $11.8 \pm 0.6$ \\
\hline & B. inermis & $960 \pm 29$ & $0.87 \pm 0.04$ & $26.9 \pm 1.7$ & $30.3 \pm 0.5$ & $28.9 \pm 0.9$ & $13.7 \pm 0.8$ & $15.6 \pm 0.6$ \\
\hline & K. cristata & $796 \pm 55$ & $0.95 \pm 0.03$ & $22.2 \pm 0.7$ & $33.0 \pm 0.5$ & $28.6 \pm 0.9$ & $16.0 \pm 0.8$ & $17.0 \pm 1.0$ \\
\hline & P. pratensis & $1054 \pm 74$ & $0.87 \pm 0.05$ & $25.4 \pm 0.7$ & $30.9 \pm 1.1$ & $25.5 \pm 0.9$ & $18.0 \pm 2.3$ & $21.7 \pm 4.0$ \\
\hline & Mean & $\mathbf{9 8 9} \pm 37$ & $0.86 \pm 0.02$ & $30.0 \pm 1.7$ & $29.5 \pm 0.7$ & $26.2 \pm 0.6$ & $14.1 \pm 0.9$ & $16.5 \pm 1.2$ \\
\hline \multirow[t]{5}{*}{ Forbs } & A. millefolium & $979 \pm 76$ & $0.86 \pm 0.06$ & $56.3 \pm 1.6$ & $12.5 \pm 0.4$ & $18.1 \pm 0.6$ & $12.9 \pm 1.0$ & $15.1 \pm 0.5$ \\
\hline & A. cylindrica & $361 \pm 49$ & $1.33 \pm 0.11$ & $41.3 \pm 4.2$ & $19.9 \pm 1.4$ & $23.3 \pm 2.0$ & $14.9 \pm 1.5$ & $11.6 \pm 1$ \\
\hline & A. tuberosa & $230 \pm 28$ & $1.37 \pm 0.14$ & $37.5 \pm 4.2$ & $22.1 \pm 1.6$ & $25.5 \pm 1.3$ & $13.7 \pm 1.9$ & $10.4 \pm 2.0$ \\
\hline & S. rigida & $963 \pm 59$ & $0.98 \pm 0.09$ & $52.6 \pm 2.8$ & $\mathbf{1 3 . 6} \pm 0.9$ & $18.5 \pm 0.9$ & $14.9 \pm 1.2$ & $15.6 \pm 1.1$ \\
\hline & Mean & $633 \pm 67$ & $1.13 \pm 0.06$ & $47.2 \pm 2.1$ & $16.9 \pm 0.9$ & $21.2 \pm 0.8$ & $14.1 \pm 0.7$ & $13.3 \pm 0.7$ \\
\hline \multirow[t]{5}{*}{ Legumes } & A. canescens & $317 \pm 41$ & $1.63 \pm 0.13$ & $30.1 \pm 1.6$ & $22.6 \pm 0.6$ & $29.6 \pm 1.1$ & $17.2 \pm 1.7$ & $11.0 \pm 1.3$ \\
\hline & L. capitata & $544 \pm 90$ & $2.03 \pm 0.08$ & $37.1 \pm 1.2$ & $23.7 \pm 0.9$ & $25.4 \pm 0.8$ & $13.4 \pm 0.9$ & $6.7 \pm 0.6$ \\
\hline & L. perennis & $625 \pm 42$ & $2.33 \pm 0.20$ & $43.6 \pm 3.1$ & $15.3 \pm 1.1$ & $26.4 \pm 1.9$ & $14.3 \pm 1.0$ & $6.1 \pm 0.7$ \\
\hline & P. villosum & $447 \pm 62$ & $1.41 \pm 0.05$ & $35.4 \pm 3.2$ & $21.6 \pm 0.9$ & $24.8 \pm 1.2$ & $17.1 \pm 1.5$ & $12.2 \pm 1.1$ \\
\hline & Mean & $483 \pm 36$ & $1.85 \pm 0.09$ & $36.3 \pm 1.4$ & $21.0 \pm 0.7$ & $26.6 \pm 0.7$ & $15.6 \pm 0.7$ & $9.1 \pm 0.7$ \\
\hline$P$-value Species id. & & $<\mathbf{0 . 0 0 0 1}$ & $<\mathbf{0 . 0 0 0 1}$ & $<\mathbf{0 . 0 0 0 1}$ & $<\mathbf{0 . 0 0 0 1}$ & $<\mathbf{0 . 0 0 0 1}$ & 0.0004 & $<\mathbf{0 . 0 0 0 1}$ \\
\hline$P$-value Funct. gr. id. & & $<0.0001$ & $<0.0001$ & $<\mathbf{0 . 0 0 0 1}$ & $<\mathbf{0 . 0 0 0 1}$ & $<\mathbf{0 . 0 0 0 1}$ & 0.21 & $<\mathbf{0 . 0 0 0 1}$ \\
\hline
\end{tabular}


Table 3. Mean values \pm standard error for labile $\mathrm{C}$, its respiration rate constant $(\boldsymbol{k})$, nonlabile soil $\mathrm{C}$ respiration rate $(c)$, and microbial $\mathrm{C}$ and $\mathrm{N}$ of the 16 different species averaged over the $\mathrm{CO}_{2}$ and $\mathrm{N}$ treatment $(n=8)$ with statistical probabilities $(P$-values) for species and functional group identity effects from analysis of variance (ANOVA, $\mathrm{CO}_{2} \times \mathbf{N} \times$ Species identity and $\mathrm{CO}_{2} \times \mathbf{N} \times \mathbf{F u n c t i o n a l}$ group identity models respectively). $\mathrm{CO}_{2}$ and $\mathrm{N}$ treatment effects are shown in Table 1.

\begin{tabular}{|c|c|c|c|c|c|c|}
\hline Functional group & Plant species & Labile C & $\boldsymbol{k}$ & $c$ & Microbial C & Microbial N \\
\hline & & $\mathbf{m g ~ k g ^ { - 1 }}$ & $\mathbf{d}^{-1}$ & $\mathrm{mg} \mathrm{kg}^{-1} \mathbf{d}^{-1}$ & 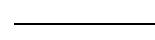 & . \\
\hline \multirow{5}{*}{ C4 grasses } & A. gerardii & $91 \pm 19$ & $0.050 \pm 0.004$ & $5.2 \pm 0.4$ & $111 \pm 13$ & $13.5 \pm 1.6$ \\
\hline & B. gracilis & $92 \pm 12$ & $\mathbf{0 . 0 5 8} \pm \mathbf{0 . 0 0 7}$ & $5.4 \pm 0.3$ & $103 \pm 7$ & $9.6 \pm 1.2$ \\
\hline & S. scoparium & $91 \pm 16$ & $0.048 \pm 0.006$ & $4.9 \pm 0.3$ & $131 \pm 9$ & $17.8 \pm 1.6$ \\
\hline & S. nutans & $135 \pm 31$ & $0.046 \pm 0.007$ & $5.5 \pm 0.4$ & $138 \pm 9$ & $17.1 \pm 1.4$ \\
\hline & Mean & $102 \pm 10$ & $\mathbf{0 . 0 5 0} \pm \mathbf{0 . 0 0 3}$ & $5.3 \pm 0.2$ & $121 \pm 5$ & $14.5 \pm 0.9$ \\
\hline \multirow[t]{5}{*}{ C3 grasses } & A. repens & $110 \pm 12$ & $0.066 \pm 0.008$ & $6.2 \pm 0.5$ & $153 \pm 10$ & $19.3 \pm 1.2$ \\
\hline & B. inermis & $76 \pm 13$ & $0.046 \pm 0.007$ & $5.8 \pm 0.4$ & $135 \pm 12$ & $20.0 \pm 2.5$ \\
\hline & K. cristata & $111 \pm 23$ & $0.058 \pm 0.006$ & $5.2 \pm 0.4$ & $128 \pm 11$ & $16.8 \pm 2.1$ \\
\hline & $P$. pratensis & $96 \pm 16$ & $\mathbf{0 . 0 5 8} \pm \mathbf{0 . 0 0 4}$ & $4.9 \pm 0.3$ & $115 \pm 10$ & $12.1 \pm 1.4$ \\
\hline & Mean & $98 \pm 8$ & $\mathbf{0 . 0 5 7} \pm \mathbf{0 . 0 0 3}$ & $5.5 \pm 0.2$ & $133 \pm 6$ & $17.1 \pm 1.0$ \\
\hline \multirow[t]{5}{*}{ Forbs } & A. millefolium & $246 \pm 44$ & $\mathbf{0 . 0 3 3} \pm \mathbf{0 . 0 0 6}$ & $6.3 \pm 0.8$ & $155 \pm 12$ & $16.0 \pm 1.5$ \\
\hline & A. cylindrica & $\mathbf{5 0} \pm \mathbf{1 0}$ & $0.042 \pm 0.004$ & $3.8 \pm 0.3$ & $107 \pm 13$ & $12.5 \pm 1.7$ \\
\hline & A. tuberosa & $89 \pm 44$ & $\mathbf{0 . 0 3 4} \pm \mathbf{0 . 0 0 8}$ & $3.0 \pm 0.5$ & $105 \pm 9$ & $14.1 \pm 1.2$ \\
\hline & S. rigida & $124 \pm 30$ & $0.043 \pm 0.004$ & $5.7 \pm 0.3$ & $137 \pm 13$ & $16.1 \pm 1.6$ \\
\hline & Mean & $131 \pm 22$ & $\mathbf{0 . 0 3 8} \pm \mathbf{0 . 0 0 3}$ & $4.7 \pm 0.3$ & $126 \pm 7$ & $14.7 \pm 0.8$ \\
\hline \multirow{5}{*}{ Legumes } & A. canescens & $46 \pm 8$ & $\mathbf{0 . 0 3 6} \pm \mathbf{0 . 0 0 5}$ & $3.3 \pm 0.2$ & $106 \pm 9$ & $12.6 \pm 0.6$ \\
\hline & L. capitata & $40 \pm 6$ & $\mathbf{0 . 0 5 6} \pm \mathbf{0 . 0 0 8}$ & $4.5 \pm 0.2$ & $110 \pm 11$ & $13.1 \pm 0.8$ \\
\hline & L. perennis & $113 \pm 25$ & $0.044 \pm 0.003$ & $4.4 \pm 0.2$ & $160 \pm 12$ & $22.7 \pm 2.0$ \\
\hline & P. villosum & $48 \pm 7$ & $0.042 \pm 0.004$ & $3.6 \pm 0.3$ & $111 \pm 18$ & $14.8 \pm 1.7$ \\
\hline & Mean & $62 \pm 8$ & $0.044 \pm 0.003$ & $4.0 \pm 0.1$ & $122 \pm 7$ & $15.8 \pm 1.0$ \\
\hline$P$-value Species id. & & $<\mathbf{0 . 0 0 0 1}$ & 0.0003 & $<\mathbf{0 . 0 0 0 1}$ & 0.0005 & $<0.0001$ \\
\hline$P$-value Funct. gr. id. & & 0.01 & 0.0002 & 0.0002 & 0.45 & 0.11 \\
\hline
\end{tabular}

among plant species in terms of total plant biomass and root chemistry responses to elevated $\mathrm{CO}_{2}$ or $\mathrm{N}$ fertilization. That is, we only found significant interactions between species identity and the $\mathrm{CO}_{2}$ and $\mathrm{N}$ treatments for total plant biomass $\left(\mathrm{CO}_{2} \times\right.$ species: $P=0.05, \mathrm{~N} \times$ species: $P=0.05)$ and $\operatorname{root} \mathrm{N}$ concentration $(\mathrm{N} \times$ species: $P=0.003)$. Most of the $\mathrm{C} 3$ plants increased in plant biomass with elevated $\mathrm{CO}_{2}$, but not the $\mathrm{C} 4$ grasses $S$. scoparium and $S$. nutans, while plant biomass and root $\mathrm{N}$ concentration of the four legumes did not respond to $\mathrm{N}$ addition as much as the other species. Plant species identity interactions with elevated $\mathrm{CO}_{2}$ and $\mathrm{N}$ fertilization in terms of plant biomass and root $\mathrm{N}$ concentration are discussed in detail by Reich et al. (2001a).

We observed large differences in labile $\mathrm{C}, k, c$, and microbial $\mathrm{C}$ and $\mathrm{N}$ among soils associated with different plant species and functional groups (Table 3). Labile C, $c$, and microbial $\mathrm{C}$ were highest and $k$ lowest in soils of the forb A. millefolium while microbial $\mathrm{N}$ was highest in soils of the $\mathrm{N}$-fixing L. perennis. Soils of the $\mathrm{C} 4$ grasses as a group had the highest labile $\mathrm{C}$, soils of the $\mathrm{C} 3$ grasses had the highest $k$ and $c$ values, soils of the forbs had the lowest $k$ value, and soils of the legumes had the lowest labile $\mathrm{C}$ and $c$ values. We found no $\mathrm{CO}_{2}$ or $\mathrm{N}$ treatment interactions with species or functional groups for labile $\mathrm{C}, k, c$, and microbial $\mathrm{C}$ and $\mathrm{N}$.

Net $\mathrm{N}$ mineralization differed significantly among plant species and functional groups (Fig. 1). Net N mineralization was on average 40 times higher for $L$. perennis than for $A$. millefolium. The $\mathrm{C} 4$ grasses had on average the lowest and the legumes the highest net $\mathrm{N}$ mineralization. As with soil $\mathrm{C}$ respiration parameters

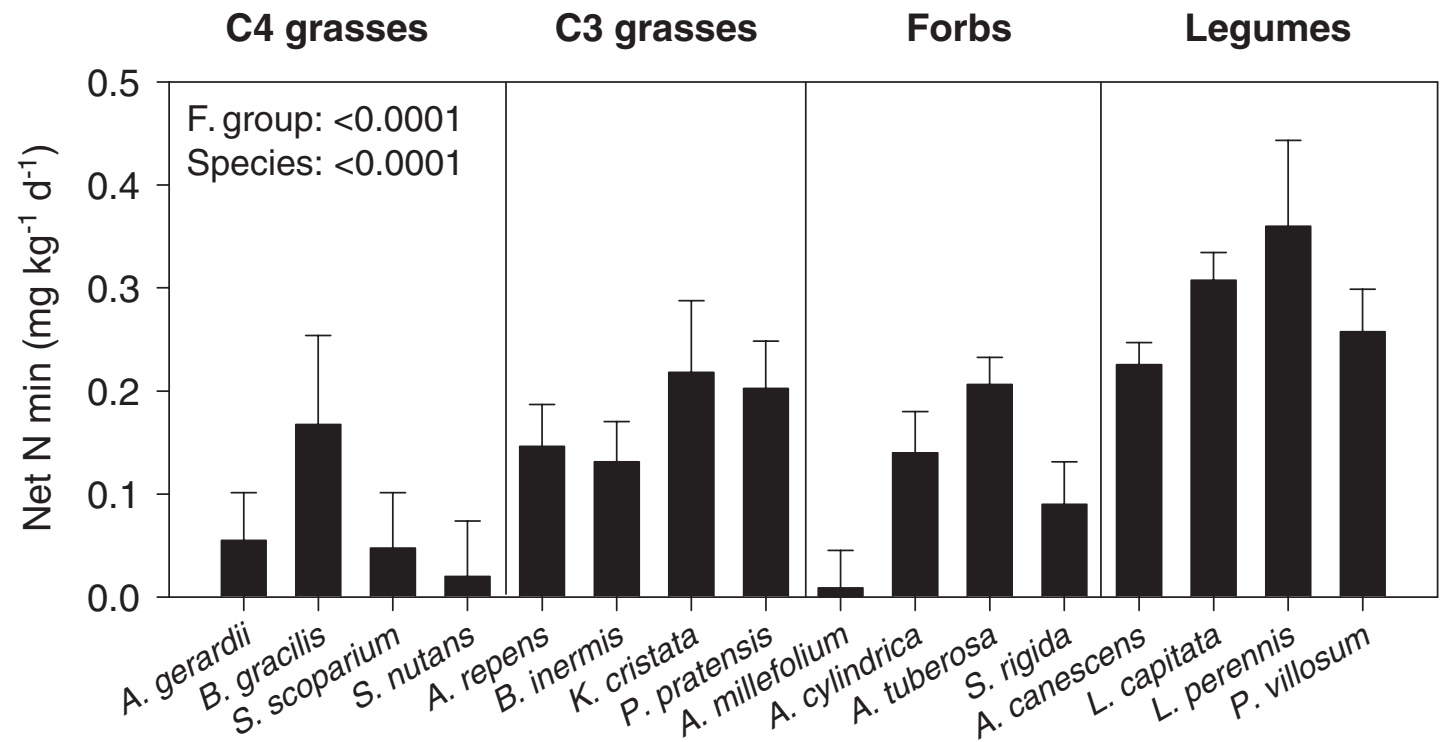

Fig. 1. Average net $\mathrm{N}$ mineralization rate separated by species (pooled across $\mathrm{CO}_{2}$ and $\mathrm{N}$ treatment). Error bars show standard error $(n=8)$. 
Table 4. Summary of multiple regressions for nonlabile soil $\mathbf{C}$ respiration rate $(c)$, microbial $C$ and $N$, and net $N$ mineralization using all 128 plots. $P$-values are shown for each independent variable and adjusted $R^{2}$ values for the whole regression.

\begin{tabular}{lcccc}
\hline Independent variable & $c$ & \multicolumn{2}{c}{ Microbial C } & Microbial N Net N min. \\
\hline Tot. plant biomass & $<\mathbf{0 . 0 0 0 1}$ & $<\mathbf{0 . 0 0 0 1}$ & $<\mathbf{0 . 0 0 0 1}$ & $\mathbf{0 . 0 7}$ \\
Root N conc. & $\mathbf{0 . 0 8}$ & $\mathbf{0 . 6 3}$ & $\mathbf{0 . 6 3}$ & $<\mathbf{0 . 0 0 0 1}$ \\
Root cell soluble conc. & $\mathbf{0 . 2 7}$ & $\mathbf{0 . 3 1}$ & $\mathbf{0 . 3 4}$ & $\mathbf{0 . 1 8}$ \\
Root hemicellulose conc. & $\mathbf{0 . 3 4}$ & $\mathbf{0 . 1 9}$ & $\mathbf{0 . 2 3}$ & $\mathbf{0 . 9 1}$ \\
Root cellulose conc. & $\mathbf{0 . 1 7}$ & $\mathbf{0 . 3 9}$ & $\mathbf{0 . 4 5}$ & $\mathbf{0 . 7 3}$ \\
Root lignin conc. & $\mathbf{0 . 3 2}$ & $\mathbf{0 . 0 9}$ & $\mathbf{0 . 0 9}$ & $\mathbf{0 . 9 6}$ \\
Labile C & $-\dagger$ & $\mathbf{0 . 0 2}$ & $\mathbf{0 . 0 3}$ & $\mathbf{0 . 0 5}$ \\
$\boldsymbol{R}^{2}$ adj & $\mathbf{0 . 4 6}$ & $\mathbf{0 . 3 0}$ & $\mathbf{0 . 1 8}$ & $\mathbf{0 . 3 3}$ \\
\hline
\end{tabular}

$\dagger$ Not included in multiple regression.

and microbial biomass, we found no $\mathrm{CO}_{2}$ or $\mathrm{N}$ treatment interactions with species or functional groups for net $\mathrm{N}$ mineralization.

Between 18 and $46 \%$ of the variation in $c$, microbial C and $\mathrm{N}$, and net $\mathrm{N}$ mineralization among species could be explained by interspecific differences in total plant biomass, root chemistry, and labile $\mathrm{C}$ inputs (Table 4). Total plant biomass had the largest effect on $c$ and microbial $\mathrm{C}$ and N. Simple regressions between total plant biomass and $c$ and microbial $\mathrm{C}$ and $\mathrm{N}$ all showed significant positive relationships $\left(c: P<0.0001, R^{2}=\right.$ 0.45 ; microbial C: $P<0.0001, R^{2}=0.13$; microbial $\mathrm{N}$ : $P=0.01, R^{2}=0.05$, Fig. 2).

The multiple regression analyses showed that labile $\mathrm{C}$ had a significant positive effect on microbial $\mathrm{C}$ and $\mathrm{N}$, and a negative effect on net $\mathrm{N}$ mineralization (Table 4). Simple regressions between microbial biomass $(\mathrm{C}$ and $\mathrm{N})$ and labile $\mathrm{C}$ showed several outliers from $A$. millefolium plots. When we excluded $A$. millefolium plots from the simple regression analyses the relationships were highly significant $\left(P<0.0001, R^{2}=0.24\right.$ for microbial $\mathrm{C}$ and $P<0.0001, R^{2}=0.26$ for microbial N). Similarly, the relationship between net $\mathrm{N}$ mineralization and labile $\mathrm{C}$ showed outliers from $L$. perennis plots. Removing L. perennis plots from the simple regression analysis with net $\mathrm{N}$ mineralization showed a significant negative relationship with labile $\mathrm{C}\left(P<0.0001, R^{2}=0.19\right)$.

Root $\mathrm{N}$ concentration was highly significantly positively related to net $\mathrm{N}$ mineralization (Table 4, Fig. 2). Although only marginally significant in the multiple regression analysis, root $\mathrm{N}$ concentration was significantly negatively related to $c\left(P<0.0001, R^{2}=0.13\right.$, Fig. 2) in a simple regression.

Root hemicellulose, root cellulose, and root lignin concentration could not explain any of the variation in $c$, microbial $\mathrm{C}$ and $\mathrm{N}$, or net $\mathrm{N}$ mineralization among species in the multiple regressions. Excluding these variables from the multiple regressions did not substantially alter the effects of the other variables (not shown).

\section{DISCUSSION}

The 16 species caused much larger variation in plant litter inputs and chemistry, as well as soil $\mathrm{C}$ and $\mathrm{N}$ dynamics, than the $\mathrm{CO}_{2}$ and $\mathrm{N}$ treatment in our study. Interspecific variation in plant litter inputs (plant productivity) and chemistry (root tissue $\mathrm{N}$ concentration) grown under different atmospheric $\mathrm{CO}_{2}$ and $\mathrm{N}$ supply explained to a large degree the variation in soil $\mathrm{C}$ and $\mathrm{N}$ dynamics in this grassland system. Our results further show that plant species grown under different atmospheric $\mathrm{CO}_{2}$ and $\mathrm{N}$ supply can also affect microbial biomass and net $\mathrm{N}$ mineralization through production of labile $\mathrm{C}$, likely from rhizodeposition. Despite significant $\mathrm{CO}_{2}$ or $\mathrm{N}$ treatment interactions with plant species for total plant biomass and root $\mathrm{N}$ concentration, there were no significant treatment interactions for microbial biomass, $\mathrm{C}$ and $\mathrm{N}$ mineralization. This suggest that in this system $4 \mathrm{yr}$ of elevated $\mathrm{CO}_{2}$ and $\mathrm{N}$ supply does not favor growth of certain plant species over others through feedback mechanisms between plant productivity and soil organic matter dynamics under monoculture. Studies addressing interactive effects of plant species, atmospheric $\mathrm{CO}_{2}$ and $\mathrm{N}$ supply, on soil $\mathrm{C}$ and $\mathrm{N}$ dynamics are scarce, and much of our understanding of how microbial biomass and activity are affected by different plant species under changing atmospheric $\mathrm{CO}_{2}$ and $\mathrm{N}$ supply remain incoherent (Bardgett et al., 1999; Zak et al., 2000). Our results indicate that the integrated effects of plant species and their responses to the $\mathrm{CO}_{2}$ and $\mathrm{N}$ treatment on plant productivity, tissue $\mathrm{N}$ concentration, and labile $\mathrm{C}$ production, can to a large degree explain variation in soil $\mathrm{C}$ and $\mathrm{N}$ dynamics in this system. It remains to be seen if elevated $\mathrm{CO}_{2}$ and $\mathrm{N}$ deposition show species-specific effects on microbial activity and soil organic matter dynamics in the long-term, and how this will affect plant community and soil organic matter dynamics in more diverse systems.

The substantial divergence in soil microbial biomass (up to twofold) and nonlabile soil $\mathrm{C}$ respiration (up to twofold) among the 16 species could in large part be explained by interspecific variation in total plant biomass and presumably the associated variation in plant $\mathrm{C}$ inputs to soils, but not by interspecific variation in root $\mathrm{C}$ chemistry such as cell solubles and lignin concentration. The positive relationship between nonlabile soil $\mathrm{C}$ respiration and total plant biomass indicates that a significant part of the nonlabile soil $\mathrm{C}$ respiration stemmed from soil $\mathrm{C}$ formed during the experiment. Greater nonlabile soil $\mathrm{C}$ respiration with greater total plant biomass may therefore have stemmed from greater litter inputs since the experiment started, which possibly may also have stimulated decomposition of pre-experiment soil C (Broadbent, 1947; Bingeman et al., 1953). Other studies have also shown that the quantity of plant $\mathrm{C}$ inputs can have a large influence on microbial biomass $\mathrm{C}$ and soil C respiration (Bardgett et al., 1999; Zak et al., 2003; Zak et al., 1994). Our results suggest that decomposition of soil organic matter (nonlabile soil $\mathrm{C}$ respiration) is sensitive to variation in the quantity of organic matter inputs, but that differences among species in root $\mathrm{C}$ chemistry largely disappear as microbes process plant litter. However, these results are in contrast with a study where we observed a significant negative effect of root lignin concentration on decomposition of old $\mathrm{C}$ (older than $5 \mathrm{yr}$ ) in elevated $\mathrm{CO}_{2}$ and $\mathrm{N}$ fertilized plots, estimated from C isotope analyses (Dijkstra et al., 2004). Our 74-d soil laboratory incubations may not have been sensitive enough to detect significant long- 


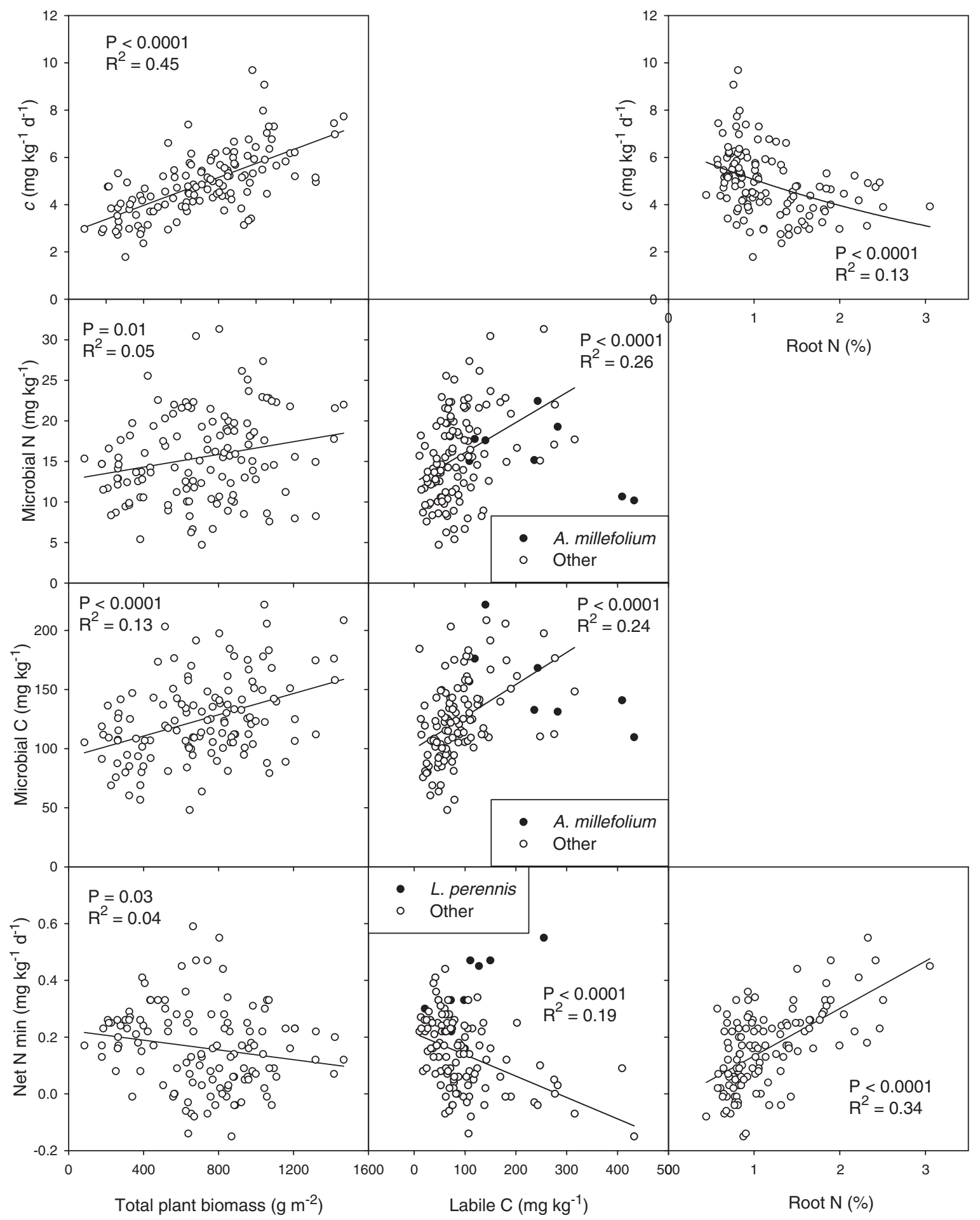

Fig. 2. Nonlabile soil $\mathrm{C}$ respiration (c), microbial $\mathrm{C}$ and $\mathrm{N}$, and net $\mathrm{N}$ mineralization rate plotted against total plant biomass, labile $\mathrm{C}$, and root $\mathrm{N}$ concentration, with regression lines. For the relationship between labile $\mathbf{C}$ and microbial $\mathrm{C}$ and $\mathbf{N} \boldsymbol{A}$. millefolium plots were excluded in the regression analyses, while for the relationship between labile $\mathrm{C}$ and net $\mathrm{N}$ mineralization $L$. perennis plots were excluded.

term effects of root $\mathrm{C}$ chemistry on decomposition of non-labile soil $\mathrm{C}$, also because we assumed that nonlabile soil C respiration rates were constant (Eq. [1]) after $74 \mathrm{~d}$. Further, under field conditions living plant roots may also have affected non-labile soil $\mathrm{C}$ decomposition through rhizosphere processes (e.g., Cheng et al., 2003;
Kuzyakov et al., 2001), which were excluded in our laboratory incubations.

In contrast to root $\mathrm{C}$ chemistry, we observed a significant root $\mathrm{N}$ concentration effect on nonlabile soil $\mathrm{C}$ decomposition. The significant negative relationship between root $\mathrm{N}$ concentration and nonlabile soil $\mathrm{C}$ respira- 
tion suggests that increased $\mathrm{N}$ concentration in roots (e.g., in forbs and especially legumes) slowed down the decomposition of more recalcitrant soil organic matter. While others have reported increased stabilization of litter at later stages of decomposition for Norway spruce litters with initially higher $\mathrm{N}$ concentrations (Berg and Matzner, 1997; Matzner, 2002), to our knowledge, our results are the first showing that variation in root $\mathrm{N}$ concentration among grassland species under different atmospheric $\mathrm{CO}_{2}$ and $\mathrm{N}$ supply can cause similar negative effects on soil organic matter decomposition.

Microbial biomass was positively related to labile $\mathrm{C}$ inputs (across species, $\mathrm{CO}_{2}$ and $\mathrm{N}$ treatment). Much of the labile $\mathrm{C}$ was likely from rhizodeposition (e.g., exudates, mucilages, and lysates) rather than solely from leaching and decomposition of dead root cell soluble contents because root cell soluble concentration alone was not significantly related to microbial biomass. Since soil microbes are usually $\mathrm{C}$ limited (Michelsen et al., 1999; Smith and Paul, 1990; Van de Geijn and van Veen, 1993), plant C inputs, especially in the form of labile C such as root exudates, play an important role in supporting microbial biomass and activity (Kuzyakov, 2002), that could further obscure possible $\mathrm{C}$ litter chemistry effects on microbial biomass and nonlabile soil $\mathrm{C}$ decomposition. One plant species, the forb A. millefolium, showed very high labile $\mathrm{C}$ pools that did not correspond to similar increases in microbial biomass $\mathrm{C}$ and $\mathrm{N}$, suggesting that this species produced labile $\mathrm{C}$ compounds that did not stimulate microbial growth. Achillea millefolium plants are rich in essential oils (terpenes) that in fact have been shown to reduce microbial activity (Candan et al., 2003; Fiori et al., 2000).

While total plant biomass (of all traits examined) showed the greatest effect on nonlabile soil C decomposition, labile $\mathrm{C}$ and root $\mathrm{N}$ concentration explained more of the variation in $\mathrm{N}$ dynamics. Low rates of net $\mathrm{N}$ mineralization were associated with large amounts of labile $\mathrm{C}$, likely because stimulation of microbial growth caused greater microbial $\mathrm{N}$ immobilization (Jonasson et al., 1996; Schmidt et al., 1997), reducing $\mathrm{N}$ availability for plant growth (Hu et al., 2001). An exception was the legume L. perennis, which showed high net $\mathrm{N}$ mineralization rates despite high amounts of labile $\mathrm{C}$, likely because of its high root $\mathrm{N}$ concentrations. Indeed, root $\mathrm{N}$ concentrations, and not root lignin or lignin/ $\mathrm{N}$ ratio, explained most of the variation in net $\mathrm{N}$ mineralization rate. Legume species (and also forbs and C3 grasses) with the highest root $\mathrm{N}$ concentration also exhibited high net $\mathrm{N}$ mineralization rates. In a study with fewer species that overlapped those studied here, net $\mathrm{N}$ mineralization rates also appeared to be best related to plant litter $\mathrm{N}$ concentrations (Wedin and Tilman, 1990). Across a range of forest sites, litter lignin/ $\mathrm{N}$ ratios showed a better relationship with net $\mathrm{N}$ mineralization rates than $\mathrm{N}$ alone (Scott and Binkley, 1997). As most of the forest sites had higher lignin/ $\mathrm{N}$ ratios than our grassland species, the effect of lignin on net $\mathrm{N}$ mineralization may be more pronounced when relatively more lignin is produced in litter.

Our results suggest that variation in soil organic matter decomposition across species in our grassland system under different atmospheric $\mathrm{CO}_{2}$ and $\mathrm{N}$ supply is more affected by variation in the amount of litter inputs (positive effect) and in root $\mathrm{N}$ concentration (negative effect), than by root $\mathrm{C}$ chemistry. In contrast, net $\mathrm{N}$ mineralization was not as sensitive to variation in the amount of litter inputs but highly sensitive to variation in the chemistry of plant inputs, increasing with root $\mathrm{N}$ concentration. Our results also indicate that, besides detrital quantity and chemistry, variation in labile $\mathrm{C}$ production, likely from rhizodeposition, can significantly affect $\mathrm{C}$ and $\mathrm{N}$ dynamics, increasing microbial biomass and reducing net $\mathrm{N}$ mineralization. We conclude that the large interspecific variability in plant productivity, tissue $\mathrm{N}$ concentration, and labile $\mathrm{C}$ production such as from rhizodeposition, and their alteration by changing atmospheric $\mathrm{CO}_{2}$ and $\mathrm{N}$ supply can cause large variation in soil $\mathrm{C}$ and $\mathrm{N}$ dynamics in a grassland ecosystem.

\section{ACKNOWLEDGMENTS}

We thank Jason West for helpful comments on an earlier draft of this manuscript, Chinelo Njaka, Jenny Goth, Jared Trost, and many undergraduate interns for field and lab work, and Steve Bauer and Jason Neff for help with chemical analyses. This research was supported by the U.S. Department of Energy and the NSF LTER (DEB-0080382) and Biocomplexity (DEB-0322057) Programs.

\section{REFERENCES}

Aerts, R., H. de Caluwe, and B. Beltman. 2003. Plant community mediated vs. nutritional controls on litter decomposition rates in grasslands. Ecology 84:3198-3208.

Bardgett, R.D., J.L. Mawdsley, P.J. Hobbs, J.S. Rodwell, and W.J. Davies. 1999. Plant species and nitrogen effects on soil biological properties of temperate upland grasslands. Funct. Ecol. 13:650-660.

Beck, T., R.G. Joergensen, E. Kandeler, F. Makeschin, E. Nuss, H.R. Oberholzer, and S. Scheu. 1997. An inter-laboratory comparison of ten different ways of measuring soil microbial biomass C. Soil Biol. Biochem. 29:1023-1032.

Berg, B., and E. Matzner. 1997. Effect of $\mathrm{N}$ deposition on decomposition of plant litter and soil organic matter in forest systems. Environ. Rev. 5:1-25.

Bingeman, C.W., J.E. Varner, and W.P. Martin. 1953. The effect of the addition of organic materials on the decomposition of an organic soil. Soil Sci. Soc. Am. Proc. 29:692-696.

Bonde, T.A., and T. Rosswall. 1987. Seasonal variation of potentially mineralizable nitrogen in four cropping systems. Soil Sci. Soc. Am. J. 51:1508-1514.

Broadbent, F.E. 1947. Nitrogen release and carbon loss from soil organic matter during decomposition of added plant residues. Soil Sci. Soc. Am. Proc. 12:246-249.

Brookes, P.C., A. Landman, G. Pruden, and D.S. Jenkinson. 1985. Chloroform fumigation and the release of soil nitrogen: A rapid direct extraction method to measure microbial biomass nitrogen in soil. Soil Biol. Biochem. 17:837-842.

Candan, F., M. Unlu, B. Tepe, D. Daferera, M. Polissiou, A. Sokmen, and H.A. Akpulat. 2003. Antioxidant and antimicrobial activity of the essential oil and methanol extracts of Achillea millefolium subsp millefolium Afan. (Asteraceae). J. Ethnopharmacol. 87:215-220.

Cheng, W., and D.W. Johnson. 1998. Elevated $\mathrm{CO}_{2}$, rhizosphere processes, and soil organic matter decomposition. Plant Soil 202:167-174.

Cheng, W.X., D.W. Johnson, and S.L. Fu. 2003. Rhizosphere effects on decomposition: Controls of plant species, phenology, and fertilization. Soil Sci. Soc. Am. J. 67:1418-1427.

Dijkstra, F.A., S.E. Hobbie, J.M.H. Knops, and P.B. Reich. 2004. Nitrogen deposition and plant species interact to influence soil carbon stabilization. Ecol. Lett. 7:1192-1198.

Dijkstra, F.A., S.E. Hobbie, P.B. Reich, and J.M.H. Knops. 2005. Divergent effects of elevated $\mathrm{CO}_{2}, \mathrm{~N}$ fertilization, and plant di- 
versity on soil $\mathrm{C}$ and $\mathrm{N}$ dynamics in a grassland field experiment. Plant Soil 272:41-52.

Eviner, V.T., and F.S. Chapin, III. 2004. Functional matrix: A conceptual framework for predicting multiple plant effects on ecosystem processes. Annu. Rev. Ecol. Syst. 34:455-485.

Finzi, A.C., C.D. Canham, and N. van Breemen. 1998. Canopy tree-soil interactions within temperate forests: Species effects on soil carbon and nitrogen. Ecol. Appl. 8:440-446.

Finzi, A.C., and A.H. Schlesinger. 2002. Specie control variation in litter decomposition in a pine forest exposed to elevated $\mathrm{CO}_{2}$. Glob. Change Biol. 8:1217-1229.

Fiori, A.C.G., K.R.F. Schwan-Estrada, J.R. Stangarlin, J.B. Vida, C.A. Scapim, M.E.S. Cruz, and S.F. Pascholati. 2000. Antifungal activity of leaf extracts and essential oils of some medicinal plants against Didymella bryoniae. J. Phytopath. 148:483-487.

$\mathrm{Fu}$, S.L., and W.X. Cheng. 2002. Rhizosphere priming effects on the decomposition of soil organic matter in C-4 and C-3 grassland soils Plant Soil 238:289-294.

Hobbie, S.E. 1992. Effects of plant species on nutrient cycling. Trends Ecol. Evol. 7:336-339.

Hobbie, S.E., and P.M. Vitousek. 2000. Nutrient limitation of decomposition of Hawaiian forests. Ecology 81:1867-1877.

Hu, S., F.S. Chapin, III, M.K. Firestone, C.B. Field, and N.R. Chiariello. 2001. Nitrogen limitation of microbial decomposition in a grassland under elevated $\mathrm{CO}_{2}$. Nature 409:188-191.

Jonasson, S., A. Michelsen, I.K. Schmidt, E.V. Nielsen, and T.V. Callaghan. 1996. Microbial biomass C, N and P in two arctic soils and responses to addition of NPK fertilizer and sugar: Implications for plant nutrient uptake. Oecologia 106:507-515.

Knicker, H., S. Saggar, R. Baumler, P.D. McIntosh, and I. KogelKnabner. 2000. Soil organic matter transformations induced by Hieracium pilosella L. In tussock grassland of New Zealand. Biol. Fertil. Soils 32:194-201.

Kuzyakov, Y. 2002. Factors affecting rhizosphere priming effects (review). J. Plant Nutr. Soil Sci. 165:382-396.

Kuzyakov, Y., H. Ehrensberger, and K. Stahr. 2001. Carbon partitioning and below-ground translocation by Lolium perenne. Soil Biol. Biochem. 33:61-74.

Mack, M.C., and C.M. D'Antonio. 2003. The effects of exotic grasses on litter decomposition in a Hawaiian woodland: The importance of indirect effects. Ecosystems 6:723-738.

Matzner, K.M.E. 2002. Nitrogen content of forest floor Oa layers affects carbon pathways and nitrogen mineralization. Soil Biol. Biochem. 34:1807-1813.

Melillo, J.M., J. Aber, and J.F. Muratore. 1982. Nitrogen and lignin control of hardwood leaf litter decomposition dynamics. Ecology 63:621-626.

Michelsen, A., E. Graglia, I.K. Schmidt, S. Jonasson, D. Sleep, and C. Quarmy. 1999. Differential responses of grass and a dwarf shrub to long-term changes in soil microbial biomass $\mathrm{C}, \mathrm{N}$ and $\mathrm{P}$ following factorial addition of NPK fertilizer, fungicide and labile carbon to a heath. New Phytol. 143:523-538.

Reich, P.B., D. Tilman, J. Craine, D. Ellsworth, M.G. Tjoelker, J. Knops, D. Wedin, S. Naeem, D. Bahauddin, J. Goth, W. Bengston, and T.D. Lee. 2001a. Do species and functional groups differ in acquisition and use of $\mathrm{C}, \mathrm{N}$ and water under varying atmospheric $\mathrm{CO}_{2}$ and $\mathrm{N}$ availability regimes? A field test with 16 grassland species. New Phytol. 150:435-448.

Reich, P.B., J. Knops, D. Tilman, J. Craine, D. Ellsworth, M. Tjoelker, T. Lee, D. Wedin, S. Naeem, D. Bahauddin, G. Hendrey, S. Jose, K. Wrage, J. Goth, and W. Bengston. 2001b. Plant diversity enhances ecosystem responses to elevated $\mathrm{CO}_{2}$ and nitrogen deposition. Nature 410:809-812.

Reid, J.B., and M.J. Goss. 1982. Suppression of Decomposition of C-14-Labeled Plant-Roots in the Presence of Living Roots of Maize and Perennial Ryegrass. J. Soil Sci. 33:387-395.

Schmidt, I.K., A. Michelsen, and S. Jonasson. 1997. Effects of labile soil carbon on nutrient partitioning between an arctic graminoid and microbes. Oecologia 112:557-565.

Scott, N.A., and D. Binkley. 1997. Foliage litter quality and annual net $\mathrm{N}$ mineralization: Comparison across North American forest sites. Oecologia 111:151-159.

Smith, J.L., and E.A. Paul. 1990. The significance of soil microbial biomass estimations, p. 357-393. In J. Bollag and G. Stotzky (ed.) Soil biochemistry. Marcel Dekker, New York.

Townsend, A.R., P.M. Vitousek, D.J. Desmarais, and A. Tharpe. 1997 Soil carbon pool structure and temperature sensitivity inferred using $\mathrm{CO}_{2}$ and ${ }^{13} \mathrm{CO}_{2}$ incubation fluxes from five Hawaiian soils. Biogeochemistry 38:1-17.

Van de Geijn, S.C., and J.A. van Veen. 1993. Implications of increased carbon dioxide levels for carbon input and turnover in soils. Vegetatio 104/105:283-292.

Van Soest, P.J. 1994 Nutritional ecology of the ruminant. Cornell Univ. Press, Ithaca, New York.

Vitousek, P.M. 1994. Beyond global warming: Ecology and global change. Ecology 75:1861-1876.

Wedin, D.A., and D. Tilman. 1990. Species effects on nitrogen cycling: A test with perennial grasses. Oecologia 84:433-441.

Wedin, D.A., and J. Pastor. 1993. Nitrogen mineralization dynamics in grass monocultures. Oecologia 96:186-192.

Zak, D.R., K.S. Pregitzer, J.S. King, and W.E. Holmes. 2000. Elevated atmospheric $\mathrm{CO}_{2}$, fine roots and the response of soil microorganisms: A review and hypothesis. New Phytol. 147:201-222.

Zak, D.R., W.E. Holmes, D.C. White, A.D. Peacock, and D. Tilman 2003. Plant diversity, soil microbial communities, and ecosystem function: Are there any links? Ecology 84:2042-2050.

Zak, D.R., D. Tilman, R.R. Parmenter, C.W. Rice, F.M. Fisher, J. Vose, D. Milchunas, and C.W. Martin. 1994. Plant production and soil microorganisms in late-successional ecosystems: A continentalscale study. Ecology 75:2333-2347. 